\title{
Does the sequence of addition of herbicide and adjuvants to the spray solution influence sicklepod control?
}

\author{
A sequência de adição de herbicida e adjuvantes \\ à calda influencia no controle de fedegoso?
}

\author{
Maria Fernanda Tavares Ramos ${ }^{1 *}$ (D), Renata Thaysa da Silva Santos ${ }^{1}$ (D), \\ Fabiano Griesang ${ }^{1}$ (D), Dieimisson Paulo Almeida' ${ }^{1}$, Marcelo da Costa Ferreira'
}

\begin{abstract}
The use of adjuvants associated with herbicides aims at improving the performance of application and the consequent increase in the biological effect of the treatment. However, the sequence of product added to the sprayer tank can influence the phytosanitary spray solution. Thus, this study aimed to evaluate the control of Senna obtusifolia as a function of the sequence of addition of the herbicide aminopyralid + fluroxypyr and adjuvants in the preparation of spray solution. Two herbicide doses (1 and $2 \mathrm{~L}$ c.p. ha $\left.\mathrm{a}^{-1}\right)$ associated with the adjuvants mineral oil (MO), silicone polyether copolymer (SIL), and a mixture of phosphatidylcholine and propionic acid (LEC), all in the proportion of $0.3 \% \mathrm{v} \mathrm{v}^{-1}$, with alternate addition to the spray solution to evaluate the effects of the preparation sequence. The spray solution volume considered was $150 \mathrm{~L} \mathrm{ha}^{-1}$. Evaluations of spray solution stability were performed from the visual evaluation of homogeneity, electrical conductivity, and $\mathrm{pH}$. The effect of treatment on S. obtusifolia control was measured using a scoring scale and dry matter. Correlation coefficients between the evaluations were also determined. No difference of the preparation sequence of spray solution was observed for stability, $\mathrm{pH}$, and electrical conductivity, but an influence was observed on S. obtusifolia control, without changing dry matter accumulation. The treatment with the adjuvant LEC previously added to the herbicide provided a higher control rate at the highest dose, while the adjuvant SIL had the opposite effect.
\end{abstract}

KEYWORDS: preparation order; pasture; weed; Senna obtusifolia.
RESUMO: O uso de adjuvantes associados a herbicidas visa melhorar o desempenho da aplicaçáo e o consequente aumento do efeito biológico do tratamento. Porém, a ordem de adição dos produtos ao tanque do pulverizador pode trazer importantes influências à calda fitossanitária. Assim, o objetivo desta pesquisa foi avaliar o controle de Senna obtusifolia em função da sequência de adição do herbicida aminopiralide + fluroxipir e de adjuvantes no preparo das caldas. Foram utilizadas duas dosagens de herbicida (1 e 2 L p.c. ha ${ }^{-1}$ ), associadas aos adjuvantes óleo mineral (OM); copolímero de poliéter e silicone (SIL); mistura de fosfatidicolina e ácido propiônico (LEC), todos na proporçáo de $0,3 \% \mathrm{v} \mathrm{v}^{-1}$, com adiçáo alternada à calda para avaliar os efeitos da sequência de preparo. $\mathrm{O}$ volume de calda considerado foi de $150 \mathrm{~L} \mathrm{ha}^{-1}$. Foram realizadas avaliaçôes da estabilidade da calda a partir da avaliaçáo visual de homogeneidade, condutividade elétrica e $\mathrm{pH}$. O efeito do tratamento no controle de $S$. obtusifolia foi mensurado por meio de uma escala de pontuação e pela massa seca. Também foram determinados os coeficientes de correlação entre as avaliaçóes. Verificou-se que não houve diferença da sequência de preparo da calda para a estabilidade, o $\mathrm{pH}$ e a condutividade elétrica. Porém, a sequência de preparo influenciou o controle inicial de $S$. obtusifolia, sem efeito sobre a massa seca. $\mathrm{O}$ tratamento com o adjuvante LEC adicionado ao herbicida proporcionou maior taxa de controle na maior dosagem, enquanto o adjuvante de SIL teve o efeito oposto.

PALAVRAS-CHAVE: ordem de preparo; pastagem; planta daninha; Senna obtusifolia.

'Faculdade de Ciências Agrarias e Veterinárias, Universidade Estadual Paulista “Júlio de Mesquita Filho" - Jaboticabal (SP), Brazil

*Corresponding author: fer_t.ramos@hotmail.com

Received on: 05/02/2018. Accepted on: 09/11/2019 


\section{INTRODUCTION}

Weeds represented predominantly by dicotyledonous shrub and tree plants correspond to one of the main factors that influence pasture development, reducing forage capacity and yield gains of cattle herds (SILVA; SILVA, 2007). Several species infest the pasture, including the species Senna obtusifolia, popularly known as sicklepod (LORENZI, 2014). It is an annual pioneer species, with high germination viability, dense root system, and wide tropical and subtropical distribution, occurring in most Brazilian biomes (TOPANOTTI et al., 2014; TAKANO et al., 2015). The application of herbicides combined with other control methods is one of the most practiced alternatives to control this plant.

The herbicide aminopyralid + fluroxypyr is indicated for the control of several pasture weeds, including S. obtusifolia, and is recommended for post-emergence application, which must be added by $0.3 \%\left(\mathrm{v} \mathrm{v}^{-1}\right)$ of adjuvants (AGROFIT, 2017). Adjuvants are added to the spray solution directly in the sprayer tank to meet some specific demand regarding physicochemical and biological properties of the spray solution by phytosanitary products, besides allowing a better distribution, deposition, and retention of droplets on the leaf surface and better absorption and penetration of the product in the weed (DECARO et al., 2016; PRADO et al., 2016; CUNHA et al., 2017). Each adjuvant has specific properties, and the proper selection is important for efficient application, given the interaction with leaf chemical composition and the way this interaction takes place (KISSMANN, 1998).

Preparation of spray solution with herbicides and adjuvants must consider the sequence in which products are added to the tank, since there may be incompatibilities between these products, resulting in loss of effectiveness in biological target control or damage to spraying equipment (CESSA et al., 2013).

The lack of information related to the sequence of addition of herbicides and adjuvants to the spray solution, the physicochemical properties of this combination, and the effects on weed control in pastures makes the scientific studies carried out in this purpose have high relevance and applicability.

Therefore, this study aimed to evaluate the control of $S$. obtusifolia as a function of the sequence of addition of the herbicide aminopyralid + fluroxypyr and adjuvants in the preparation of spray solution.

\section{MATERIAL AND METHODS}

The study of the effects of the sequence of addition of herbicides and adjuvants in the preparation of spray solution was carried out in 2016 in a completely randomized design with four replications, arranged in a $2 \times 3+1$ factorial arrangement. The interaction factors consisted of two treatments related to the order of spray solution preparation (herbicide + adjuvant and adjuvant + herbicide) and three adjuvants, with water as control (Table 1).
The herbicide used was aminopyralid + fluroxypyr (Dominum ${ }^{\oplus} 40.0+80$ g a.e. L L ${ }^{-1}$, SL, Dow AgroSciences), belonging to the chemical groups pyridinecarboxylic acid (aminopyralid) and pyridinyloxyalkanoic acid (fluroxypyr), with registration for the species $S$. obtusifolia in pastures, and associated with three adjuvants: aliphatic hydrocarbons (mineral oil: Nimbus ${ }^{\circledR}, 428.0 \mathrm{~g}$ a.i. $\mathrm{L}^{-1}, \mathrm{CE}$, Syngenta); organosiliconate (silicone polyether copolymer: Silwet ${ }^{\circledR}, 1000 \mathrm{~g}$ a.i. $\left.\mathrm{L}^{-1}\right)$; and mixture of phosphatidylcholine (lectin) and propionic acid (LI-700 ${ }^{\circledR}$, 712.88 g a.i. L ${ }^{-1}$, CE, De Sangosse Agrochemical). Each adjuvant was added to the spray solution at a dose of $0.3 \% \mathrm{v} \mathrm{v}^{-1}$, alternating with the herbicide (Table 1), as recommended in the herbicide package insert. An application rate of $150 \mathrm{~L} \mathrm{ha}^{-1}$, commonly practiced by cattle breeders, was used as a base.

Two experiments were carried out: one at a dose of $1 \mathrm{~L}$ of herbicide ha ${ }^{-1}$ (Experiment I) and other at a dose of $2 \mathrm{~L} \mathrm{ha}^{-1}$ (Experiment II). Besides S. obtusifolia, the control of other species of broadleaved weeds present in pastures was also considered (Table 1).

Spray solution stability was evaluated using $250 \mathrm{~mL}$ graduated beakers, analytical scale, and graduated pipette. Treatments were arranged in beakers and manually stirred for 10 vertical inversions, followed by visual evaluation of liquid homogeneity, formation of foaming, cream, crystals, sedimentation, lumps, flocculation, phase separation, and oil separation, as provided in NBR-13875 (ABNT, 2014). Electrical conductivity (Marth ${ }^{\circledR}$ MP11P conductivity meter) and pH (Quimis ${ }^{\circledR}$ Q400AS), which are relevant in product degradation in the spray solution, were also measured. Measurements were performed directly in beakers containing treatments.

The species S. obtusifolia was sown in pots containing five liters of a substrate composed of soil, sand, and cattle manure (3:3:1). Three seeds were sown per pot, incorporated into one centimeter from the substrate surface. Plants were irrigated daily and maintained under open environment conditions.

Herbicide was applied in late post-emergence of $S$. obtusifolia at 65 days after sowing, commonly practiced in production

Table 1. Treatments used for evaluations of compatibility, $\mathrm{pH}$, electrical conductivity, control, and dry matter of the two experiments, with their respective sequences of preparation.

\begin{tabular}{lc} 
Treatment & Preparation Sequence ${ }^{1,2}$ \\
\hline 1 & Control \\
\hline 2 & ${ }^{3} \mathrm{Herb}+{ }^{3} \mathrm{MO}$ \\
\hline 3 & $\mathrm{Herb}+{ }^{3} \mathrm{Sil}$ \\
\hline 4 & $\mathrm{Herb}+{ }^{3} \mathrm{LeC}$ \\
\hline 5 & $\mathrm{MO}+$ Herb \\
\hline 6 & $\mathrm{Sil}+$ Herb \\
\hline 7 & Lec + Herb \\
\hline
\end{tabular}

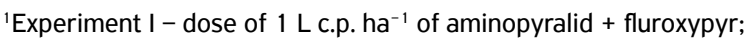
${ }^{2}$ Experiment II - dose of $2 \mathrm{~L}$ c.p. ha $^{-1}$ of aminopyralid + fluroxypyr. ${ }^{3}$ Acronyms: Herb: aminopyralid + fluroxypyr; MO: mineral oil; Sil: silicone polyether copolymer; Lec: mixture of phosphatidylcholine (lectin) and propionic acid. 
areas. Plants had an average height of $70 \mathrm{~cm}$ and were at the reproductive phase BBCH 75 (BLEIHOLDER et al., 1991). Treatments were applied using a $\mathrm{CO}_{2}$-pressurized four-wheelmounted sprayer equipped with a boom containing three spray nozzles positioned at the height of $60 \mathrm{~cm}$ from the top of the plants. Working speed was $6.3 \mathrm{~km} \mathrm{~h}^{-1}$, and working pressure was 1.2 bar (18 psi). The spray tip used was TT11003, with a flow rate of $0.79 \mathrm{~L} \mathrm{~min}^{-1}$, with thick droplet formation (TEEJET TECHNOLOGIES, 2014).

Meteorological conditions were monitored with a digital thermohygroanemometer, and temperatures, relative humidity, and wind speed were recorded at each treatment application. The temperature ranged from 28.4 to $34.9^{\circ} \mathrm{C}$ and relative humidity between 72 and $49 \%$. Wind at application time ranged from zero to $7.5 \mathrm{~km} \mathrm{~h}^{-1}$ on a sunny day with no clouds.

After application, pots were maintained under an open environment and the conditions before the application. Intoxication evaluations were made at 6,10 , and 14 days after application (DAA). A scoring scale was used for the evaluation of plant intoxication. This scale ranges from zero to ten, being zero the score referring to the absence of phytointoxication symptom and ten the plant death (NASCIMENTO; YAMASHITA, 2009). The shoot dry matter was determined after the last evaluation at $14 \mathrm{DAA}$. Plants were cut at soil level, collected, stored in paper bags, and placed in a forced-air oven at $60 \pm 5^{\circ} \mathrm{C}$ for 72 hours. Dry matter was determined on a two-decimal-place precision scale (Mettler ${ }^{\circledR}$ PC440).

The results were submitted to analysis of variance by the F-test and treatment means compared by the Tukey test $(\mathrm{p}>0.05)$ using the software AgroEstat ${ }^{\oplus}$ (BARBOSA; MALDONADO, 2015). Pearson's correlation coefficient was determined between the characteristics of the spray solution and S. obtusifolia control to verify the joint interaction of factors, two by two.

\section{RESULTS AND DISCUSSION}

A variable effect was observed for stability, $\mathrm{pH}$, and electrical conductivity depending on herbicide dose, with an interaction between the evaluated treatments.
Regarding S. obtusifolia control, preparation sequence resulted in differences to control the early stages of plant development, but without effect on dry matter production in the final evaluations.

Immediately after the preparation of spray solutions at doses of 1 and $2 \mathrm{~L} \mathrm{ha}^{-1}$ of the herbicide aminopyralid + fluroxypyr (Experiments I and II, respectively), foam formation was observed in all treatments, regardless of the sequence of product addition. Foaming at the time of spray solution preparation is an undesirable feature, as it is difficult to define the total content in the tank due to the space occupied by the foam that should be filled by the spray solution. It results in concentration errors or spills, with imminent environmental contamination (MACIEL et al., 2010). When it occurs in agricultural applications, it is necessary to stop adding water to the sprayer tank, extending the preparation time, which results in loss of operating capacity (MACIEL et al., 2010). Another alternative is to use antifoam adjuvants, which require additional investment from the farmer to correct the operation of spray solution preparation.

In Experiment I, crystals were formed only for the spray solution in which the adjuvant LEC was added before the herbicide. On the other hand, crystal formation was observed in both preparation sequences at the highest dose. Crystal occurrence in spray solutions prepared with the adjuvant LEC may be related to its specific characteristics, acting on $\mathrm{pH}$ and may interfere with the physicochemical characteristics of spray solutions (IOST; RAETANO, 2010; PRADO et al., 2016).

Crystal formation in phytosanitary spray solutions visually expresses reactions between products added to the sprayer tank, changing the characteristics related to their concentration and nature. Thus, weed control may be impaired, aggravated by any clogging in the hydraulic circuit (spray tips, filters, and connectors), resulting in uneven herbicide application in the field (PETTER et al., 2012). Because this parameter of spray solution stability did not result in reduced control of S. obtusifolia, it is possible that its effect was minimized due to an improvement in other interactions with the herbicide.

The values obtained for electrical conductivity and $\mathrm{pH}$ at a dose of $1 \mathrm{~L} \mathrm{c.p.} \mathrm{ha} \mathrm{a}^{-1}$ did not differ for the sequence of addition of the product to the spray solution (Table 2). The evaluated

Table 2. F-values and coefficients of variation applied to means of electrical conductivity $\left(\mu \mathrm{S}^{-1}\right)$ and $\mathrm{pH}$ of $\mathrm{spray}$ solutions for experiments I and II.

\begin{tabular}{|c|c|c|c|c|}
\hline \multirow{2}{*}{ Factor } & \multicolumn{2}{|c|}{ 'Experimento I } & \multicolumn{2}{|c|}{${ }^{2}$ Experimento II } \\
\hline & EC & $\mathrm{pH}$ & EC & $\mathrm{pH}$ \\
\hline Preparation sequence & $3.43^{\mathrm{ns}}$ & $0.97^{\text {ns }}$ & $0.00^{\text {ns }}$ & $0.24^{\text {ns }}$ \\
\hline Adjuvant & 851.60 ** & $3718.52 * *$ & 459.86 ** & 3232.16 ** \\
\hline Preparation sequence vs. adjuvant & $1.55^{\mathrm{ns}}$ & 0.52 ns & 4.78 * & $0.31^{\text {ns }}$ \\
\hline Treatments vs. control & 2957.52 ** & 1678.50 ** & 6078.58 ** & $0.31^{\text {ns }}$ \\
\hline CV (\%) & 2.88 & 1.65 & 2.17 & 1.67 \\
\hline
\end{tabular}

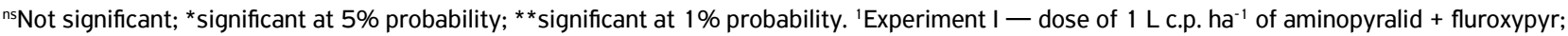
${ }^{2}$ Experiment II - dose of 2 L c.p. ha ${ }^{-1}$ of aminopyralid + fluroxypyr. 
adjuvants presented a significant difference for $\mathrm{pH}(8.8,8.5$, and 3.4 for MO, SIL, and LEC, respectively) and electrical conductivity (294.9, 187.5, and 175.0 for LEC, SIL, and MO respectively).

Usually, spray solutions with $\mathrm{pH}$ values ranging from 3.5 to 5.5 favor herbicide action (DAN et al., 2009). The adjuvant LEC acted as an acidifier in the spray solution and may have reduced herbicide alkaline hydrolysis in the spray solution, favoring control efficiency. The maintenance of herbicide activity is also due to higher absorption of spray solution by plants because the molecules are not dissociated in the solution (INOUE et al., 2007; INOUE et al., 2008; CUNHA; ALVES, 2009). The addition of MO to herbicide spray solutions increases the $\mathrm{pH}$ value (CUNHA et al., 2017), and may have decreased the efficiency of herbicides better absorbed at an acid $\mathrm{pH}$, such as auxin mimics used in this study.

The dose of $2 \mathrm{~L} \mathrm{ha}^{-1}$ showed different electrical conductivity values between adjuvants, but not differing regarding the

Table 3. Slicing of the significant interaction of electrical conductivity $\left(\mu \mathrm{S} \mathrm{cm}^{-1}\right)$ of the spray solution at a dose of $2 \mathrm{~L} \mathrm{ha}^{-1}$ of herbicide for the factors preparation sequence and adjuvants.

\begin{tabular}{lccc|} 
Preparation & \multicolumn{3}{c}{ Adjuvant } \\
\cline { 2 - 4 } sequence & MO & SIL & LEC + AP \\
\hline Herb. + Adj. & $346.3 \mathrm{Ab}$ & $339.2 \mathrm{Ab}$ & $442.1 \mathrm{Aa}$ \\
\hline Adj. + Herb. & $332.5 \mathrm{Bb}$ & $342.5 \mathrm{Ab}$ & $453.0 \mathrm{Aa}$ \\
\hline LSD columns & & 12,39 & \\
\hline LSD rows & & 15,13 & \\
\hline
\end{tabular}

Herb.: herbicide; Adj.: adjuvant. Means followed by the same lowercase letter in the rows and uppercase letter in the columns do not differ from each other by the Tukey test $(p<0.05)$. LSD: least significant difference. sequence spray solution preparation (Table 2). A significant interaction was found between the preparation sequence and adjuvants. Spray solutions containing LEC presented a higher value of electrical conductivity regardless of the preparation sequence (Table 3). A higher electrical conductivity value was observed for the adjuvant MO when the herbicide was first added to the spray solution.

The preparation sequence of spray solution did not significantly change the $\mathrm{pH}$ value (Table 2 ). However, the spray solutions composed by the different adjuvants differed from each other, and that containing LEC had a lower $\mathrm{pH}$ value (3.50).

A high negative correlation was observed between $\mathrm{pH}$ and electrical conductivity (Table 4), so that as the $\mathrm{pH}$ decreased, electrical conductivity increased.

The $\mathrm{pH}$ values were negatively correlated to weed control (lower $\mathrm{pH}$ resulted in higher control), which may be related to the preservation of herbicide molecule by reducing alkaline hydrolysis (INOUE et al., 2007; INOUE et al., 2008).

A strong positive correlation was observed between electrical conductivity and control scores, so that the higher the electrical conductivity value, the higher the weed control. It can be due to the interaction with the surface and plant metabolism, given the specific properties of leaf chemical composition and the way the interaction takes place (KISSMANN, 1998). Items such as ion concentration on the surface and inside cells, as well as the modification of morphological characteristics of epicuticle cells may alter the absorption or translocation rate of molecules by plant structure and metabolism (PIGNATELLO; XING, 1995). Herbicide can be absorbed inter- and intracellularly, requiring more or less energy consumption. These pathways imply metabolic routes with ion exchange whose availability in the formulation may favor

Table 4. Pearson's correlation coefficients between the physicochemical characteristics of the spray solution ( $\mathrm{pH}$ and electrical conductivity) and the evaluations of control (visual evaluation and dry matter).

\begin{tabular}{|c|c|c|c|c|c|c|c|}
\hline \multirow{2}{*}{ Correlation } & & \multirow{2}{*}{ pH } & \multirow{2}{*}{$\mathrm{EC}^{1}$} & \multicolumn{3}{|c|}{ Control } & \multirow{2}{*}{$\mathrm{DM}^{3}$} \\
\hline & & & & $6 \mathrm{DAA}^{2}$ & 10 DAA & 14 DAA & \\
\hline \multirow{6}{*}{ Experiment I } & $\mathrm{pH}$ & 1 & & & & & \\
\hline & EC & -0.89 & 1 & & & & \\
\hline & Control 6 DAA & -0.41 & 0.77 & 1 & & & \\
\hline & Control $10 \mathrm{DAA}$ & -0.66 & 0.92 & 0.95 & 1 & & \\
\hline & Control 14 DAA & -0.57 & 0.88 & 0.96 & 0.98 & 1 & \\
\hline & DM & 0.59 & -0.82 & -0.83 & -0.86 & -0.85 & 1 \\
\hline \multirow{6}{*}{ Experiment II } & $\mathrm{pH}$ & 1 & & & & & \\
\hline & EC & -0.77 & 1 & & & & \\
\hline & Control 6 DAA & -0.56 & 0.91 & 1 & & & \\
\hline & Control 10 DAA & -0.58 & 0.95 & 0.98 & 1 & & \\
\hline & Control 14 DAA & -0.49 & 0.93 & 0.92 & 0.97 & 1 & \\
\hline & DM & 0.29 & -0.78 & -0.86 & -0.89 & -0.89 & 1 \\
\hline
\end{tabular}

'EC: electrical conductivity; ${ }^{2} \mathrm{DAA}$ : days after application; ${ }^{3} \mathrm{DM}$ : dry matter. 
herbicide absorption, translocation, and effect (DURIGAN, 1993), once both the $\mathrm{pH}$ value and the available ions are favorable to herbicide action.

Regarding S. obtusifolia control, the different evaluated adjuvants did not differ at six DAA at a dose of $1 \mathrm{~L} \mathrm{c.p.} \mathrm{ha-1}$. Herbicide spray solution associated with $\mathrm{MO}$ showed a lower control score at 10 DAA (Fig. 1A) and treatments showed a similar control at 14 DAA. The preparation sequence of spray solution resulted in lower S. obtusifolia control only for adjuvant SIL when added before herbicide, verified at 6 DAA at a dose of $1 \mathrm{~L} \mathrm{ha}^{-1}$ (Fig. 1A) and 10 DAA at a dose of $2 \mathrm{~L} \mathrm{ha}^{-1}$ (Fig. 1B). Given the foaming observed in organosilicone adjuvants, it is recommended they be added to the sprayer tank after the herbicide has been added to the water (Embrapa, 2004). Thus, although the adjuvant SIL has a very spreading action on the leaf surface (MACIEL et al., 2011), which provides a significantly increased coverage area, it does not directly result in a higher biological efficiency (STOCK; BRIGGS, 2000), given the interactions between formulations and between the molecules of products used and the effects on the plant surface where the droplets were deposited (DURIGAN, 1993).

The dose of $2 \mathrm{~L} \mathrm{ha}^{-1}$ (Experiment II) presented an interference in S. obtusifolia control regarding the preparation sequence only for the adjuvant LEC at 6 and 10 DAA, with a higher control when added before herbicide. Even though there is no difference in the dry matter of S. obtusifolia at the end of the study period, the association LEC + HERB may provide an early action of the herbicide and, consequently, favor crop development, reducing the competition period for light, water, and nutrients (KUVA et al., 2001). The penetrating action of this adjuvant may have contributed to the herbicide entry into the leaf, accelerating the systemic action of the product at a higher dose.

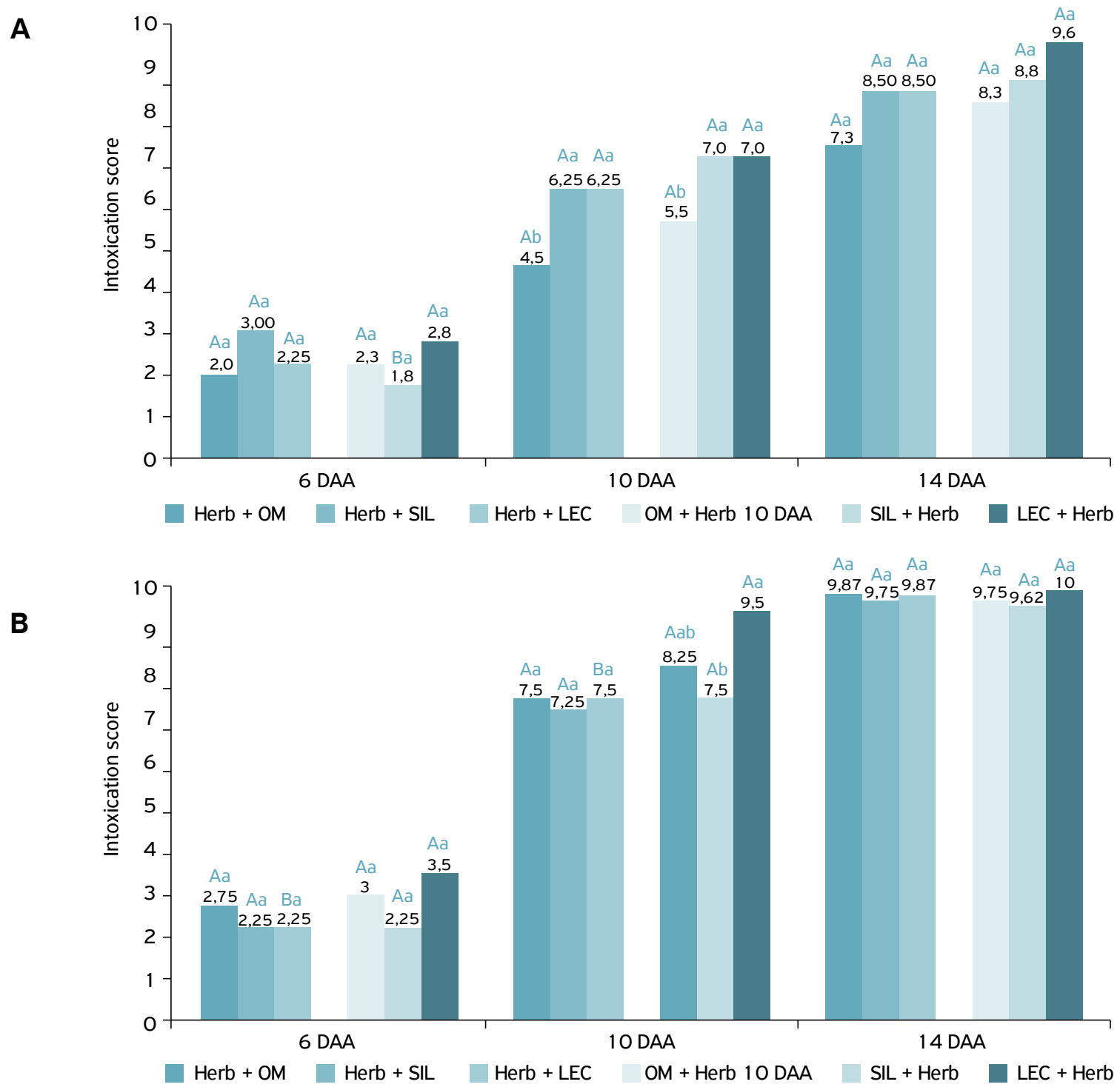

Figure 1. Scores attributed to the visual evaluation of intoxication of S. obtusifolia plants at 6, 10, and 14 days after application. (A) Experiment I (dose of 1 L c.p. ha ${ }^{-1}$ ) and (B) Experiment II (dose of 2 L c.p. ha ${ }^{-1}$ ). Uppercase letters refer to the preparation sequence and lowercase letters refer to adjuvants. Equal letters do not differ from each other by the Tukey test $(p<0.05)$. 
The anticipated action of an herbicide in weed management is important because it is from the period prior to interference (PPI) that yield is significantly affected (AGOSTINETTO et al., 2008). The critical period of interference in pastures ranges from 9 to 26 days after forage emergence (JAKELAITIS et al., 2010). In this sense, no competition between weeds and forage should occur during this period. Thus, herbicide application should be performed in PPI with manifestation of weed control before the critical period of weed interference. The importance of techniques that anticipate the action of control, naturally maintaining the effectiveness of treatments, is evident.

\section{CONCLUSION}

The sequence of addition of herbicides and adjuvants to the spray solution does not affect its stability, $\mathrm{pH}$, and electrical conductivity, but influences $S$. obtusifolia control in a specific way.

The adjuvant LEC previously added to the herbicide resulted in higher control rate and intensity, while the adjuvant SIL had the opposite effect.

The difference in weed control in the early periods of development did not change dry matter accumulation at the end of its cycle.

Spray solutions with higher electrical conductivity led to higher S. obtusifolia control.

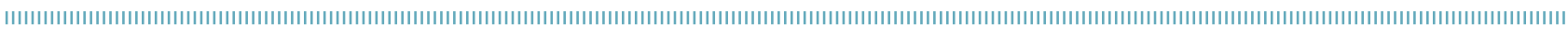
REFERENCES

AGOSTINETTO, D.; RIGOLI, R.P.; SCHAEDLER, C.E.; TIRONI, S.P.; SANTOS, L.S. Período crítico de competição de plantas daninhas com a cultura do trigo. Planta Daninha, Viçosa, v.26, n.2, p.271278, 2008. Available from: http://www.scielo.br/pdf/pd/v26n2/ a03v26n2.pdf. Access on: Mar. 072017.

AGROFIT. Sistema de Agrotóxicos Fitossanitários. Brasília: Ministério da Agricultura. Available from: http://agrofit.agricultura.gov.br/ agrofit_cons/principal_agrofit_cons. Access on: Jul. 162017.

ASSOCIAÇÃO BRASILEIRA DE NORMAS TÉCNICAS (ABNT). Agrotóxicos e afins - Avaliação de compatibilidade físico-química, NBR-13875. Rio de Janeiro: ABNT, 2014.

BARBOSA, J.C.; MALDONADO JÚNIOR, W. AgroEstat: Sistema para análises estatísticas de ensaios agronômicos. Jaboticabal: Universidade Estadual Paulista, 2015. 1 CD-ROM.

BLEIHOLDER,H.; KIRFEL, H.; LANGELÜDDEKE,P.; ATAUSS. R. Codificação unificada dos estádios fenológicos de culturas e ervas daninhas. Pesquisa Agropecuária Brasileira, Brasília, v.26, n.9, p.1423-1429, 1991. Available from: https://www.embrapa.br/busca-de-publicacoes/-/ publicacao/106153/codificacao-unificada-dos-estadios-fenologicosde-culturas-e-ervas-daninhas. Access on: Ago. 262017.

CESSA, R.M.A.; HONAISER, A.C.; MELO, E.P.; LIMA JUNIOR, I.S. Dessecação de Brachiaria decumbens: ordem de preparo e constituintes da calda de pulverização. Revista Ciências Exatas e da Terra UNIGRAN, v.2, n. 1, p.33-40, 2013. Available from: http://www.unigran.br/ciencias_ exatas/conteudo/ed2/artigos/05.pdf. Access on: Dec. 082016.

CUNHA, J.P.A.R.; ALVES, G.S. Características físico-químicas de soluções aquosas com adjuvantes de uso agrícola. Interciência, Caracas, v.34, n.9, p.655-659, 2009. Available from: http://ve.scielo. org/scielo.php?pid=S0378-18442009000900012\&script=sci_ abstract\&tlng=pt. Access on: Feb. 162017.

CUNHA, J.P.A.R.; ALVES, G.S.; MARQUES, R.S. Tensão superficial, potencial hidrogeniônico e condutividade elétrica de caldas de produtos fitossanitários e adjuvantes. Revista Ciência Agronômica, v.48, n.2, p.261-270, 2017. Available from: http://www.scielo. $\mathrm{br} / \mathrm{pdf} / \mathrm{rca} / \mathrm{v} 48 \mathrm{n} 2 / 1806-6690-\mathrm{rca}-48-02-0261$.pdf. Access on: Jul. 172017.
DAN, H.A.; DAN, L.G.M.; BARROSO, A.L.L.; SOUZA, C.H. Efeito do $\mathrm{pH}$ da calda de pulverização da dessecação de Braquiaria Brizanta com o herbicida glyphosate. Global Science and Technology, v.2, n. 1, p.1-6, 2009. Available from: https://rv.ifgoiano.edu. $\mathrm{br} /$ periodicos/index.php/gst/article/view/6. Access on: May 122017.

EMBRAPA. Reunião de Pesquisa de Soja na Região Sul, 32. Indicações técnicas para a cultura de soja no Rio Grande do Sul e Santa Catarina. Passo Fundo: Embrapa Trigo, 2004. p.149. Available from: http://www.cnpt.embrapa.br/sist-prod/sojaO4/ index.htm. Access on: Sep. 042017.

INOUE, M.H.; KOMATSU, R.A.; GUERREIRO, R.M.; DALLACORT, R.; SANTANA, D.C.; SANTANA, C.T.C. Adição de redutores de pH e doses de glyphosate na dessecação de plantas daninhas. Revista Brasileira de Herbicidas, v.6, n1, p.22-31, 2007. Available from: http://www.rbherbicidas.com.br/index.php/rbh/article/view/51/ pdf. Access on: Apr. 142017.

INOUE, M.H.; KOMATSU, R.A.; TANAHASHI, R.F.; POSSAMAI, A.C.S.; DALLACORT, R.; PIZA, M.A. Redutores de pH e complexantes de metais em condições de laboratório. Revista Brasileira de Herbicidas, v.7, n.1, p.26-35, 2008. Available from : http:// www.rbherbicidas.com.br/index.php/rbh/article/view/52/pdf. Access on: Apr. 142017.

DECARO, R.A.; DECARO JUNIOR, S.T.; FERREIRA, M.C. Deposito of pesticides without and with adjuvants on citrus seedlings following diferente intervals of artificial rain. Ciência Rural, v.46, n. 1, p.13-19, 2016. Available from: http://www.scielo.br/scielo. php?script=sci_arttext\&pid=SO 103-84782016000100013. Access on: Ago. 282019.

DURIGAN, J.C. Efeitos de adjuvantes na aplicação e eficácia de herbicidas. Jaboticabal: FUNEP, 1993. 42p.

IOST, C.A.R.; RAETANO, C.G. Tensão superficial dinâmica e ângulo de contato de soluções aquosas com surfactante em superfícies artificiais e naturais. Engenharia Agrícola, Jaboticabal, v.30, n.4, p.670-680, 2010. Available from: http://www.scielo.br/pdf/ eagri/v30n4/11.pdf. Access on: Feb. 052017. 
JAKELAITIS, A.; GIL, J.O.; SIMÕES, L.P.; SOUZA, K.V.; LUDTKE, J. Efeitos da interferência de plantas daninhas na implantação de pastagem de Brachiaria Brizantha. Revista Caatinga, Mossoró, v.23, n. 1, p.8-14, 2010. Available from: https://periodicos.ufersa. edu.br/index.php/caatinga/article/view/1332/pdf. Access on: Sep. 292017.

KISSMANN, K.G. Adjuvantes para caldas de produtos fitossanitários. In: GUEDES, J.V.C.; DORNELLES, S.B. (Org.). Tecnologia e segurança na aplicação de agrotóxicos: novas tecnologias. Santa Maria: Departamento de Defesa Fitossanitária; Sociedade de Agronomia de Santa Maria. 1998, p.39-51.

KUVA, M.A.; GRAVENA, R.; PITELLI, R.A.; CHISTOFFOLETI, P.J.; ALVES, P.L.C.A. Períodos de interferência das plantas daninhas na cultura da cana-de-açúcar II - Capim-Braquiária (Brachiaria decumbens). Planta Daninha, Viçosa, v.19, n.1, p.323-330, 2001. Available from: http://www.scielo.br/pdf/pd/v19n3/03. pdf. Access on: Sep. 262017.

LORENZI, H. Manual de identificação e controle de plantas daninhas: Plantio Direto e Convencional. 7. ed. Nova Odessa: Instituto Plantarum, 2014. p.186-187.

MACIEL, C.D.G.; GUERRA, N.; OLIVEIRA NETO, A. M.; POLETINE, J. P.; BASTOS, S. L. W.; DIAS, N. M. S. Tensão superficial estática de misturas em tanque de Glyphosate + ChlorimuronEthyl isoladas ou associadas a adjuvantes. Planta Daninha, Viçosa, v.28, n.3, p.673-685, 2010. Available from: http://www.scielo.br/pdf/pd/v28n3/25.pdf. Access on: Feb. 022017.

MACIEL, C.D.G.; POLETINE, J.P.; OLIVEIRA NETO, A.M.; GUERRA, N.; JUSTINIANO, W. Eficiência de Paraquat e MSMA isolados e associados a adjuvantes no manejo de plantas daninhas. Global Science and Technology, v.4, n. 1, p.70-81, 2011. Available from: https://rv.ifgoiano.edu.br/periodicos/index.php/gst/article/ view/252/240. Access on: Mar. 212017.

NASCIMENTO, E.R.; YAMASHITA, O.M. Desenvolvimento inicial de olerícolas cultivadas em solos contaminados com resíduos de 2,4-d + picloram. Semina: Ciências Agrárias, Londrina, v.30, n. 1 , p.47-54, 2009. Available from: http://www.uel.br/revistas/uel/ index.php/semagrarias/article/viewFile/2622/2284. Access on: Ago. 152017.
PETTER, F.A.; SEGATE, D.; PACHECO, L.P.; ALMEIDA, F.A.; ALCÂNTARA NETO, F. Incompatibilidade física de misturas entre herbicidas e inseticidas. Planta Daninha, Viçosa, v.30, n.2, p.449-457, 2012. Available from: http://www.scielo.br/scielo.php?script=sci_arttext\& pid=SO100-83582012000200025. Access on: Nov. 202016.

PIGNATELLO, J.J.; XING B. Mechanisms of slow sorption of organic chemicals to natural particles. Environmental Science $\curvearrowright$ Technology, v.30, n. 1, p.1-1 1, 1995. Available from: http://pubs.acs.org/doi/ abs/10.1021/es940683g. Access on: Jul. 162017.

PRADO, E.P; RAETANO, C.G.; DAL POGETTO, M.H.F.A.; CHECHETTO, R.G.; FERREIRA FILHO, P.J.; MAGALHÃES, A.C.; MIASAKI, C.T. Effects of agricultural spray adjuvants in surface tension reduction and spray retention on Eucalyptus leaves. African Journal of Agricultural Research, v. 1 1, n.40, p.3959-3965, 2016. Available from: http://www.academicjournals.org/journal/AJAR/articlefull-text-pdf/4EDOCBF60939. Access on: Jun. 03 2017. http:// dx.doi.org/10.5897/AJAR2016.11349

SILVA, A.A.; SILVA, J.F. Tópicos em manejo de plantas daninhas. Viçosa: Editora UFV, 2007. 357p.

STOCK, D.; BRIGGS, G. Physicochemical properties of adjuvants: values and applications. Weed Technology, v.14, n.4, p.798-806, 2000. Available from: https://www.jstor.org/stable/3988671 ?seq=1\#page_ scan_tab_contents. Access on: Ago. 212017.

TAKANO, H.K.; CONSTANTIN, J.; BRAZ, G.B.P.; LIMA, M.S.; PADOVESE FILHO, J.C.; GONÇALVES, V.D.B.; COLEVATE, A.F.K. Dry season soil texture affect chemical control of Senna obtusifolia in sugarcane. Revista Brasileira de Herbicidas. v.14, n.3, p.181-193, 2015. Available from: http://www.rbherbicidas.com.br/index.php/rbh/ article/viewFile/403/403. Access on: May 22 2017. https:// doi.org/10.7824/rbh.v14i3.403

TEEJET TECHNOLOGIES. Catálogo 51 A-PT. Wheaton: Spraying Systems Co., 2014. 164p.

TOPANOTTI, L.R.; PEREIRA, P.H.; BECHARA, F.C. Germinação de sementes de Senna obtusifolia (L.) H. S. Irwin \& Barnery (Fabaceae) visando a restauração de áreas degradadas. Publicatio UEPG: Ciências Biológicas e da Saúde, v.20, n.2, p.125-129, 2014. Available from: http://www.revistas2.uepg.br/index.php/ biologica/article/view/6957. Access on: Ago. 02 2017. http:// dx.doi.org/10.5212/Publ.Biologicas.v.20i2.0004 